\title{
ОСОБЕННОСТИ РАСПРЕДЕЛЕНИЯ РЗЭ В МЕТАПЕСЧАНИКАХ СВЕТЛИНСКОЙ СВИТЫ (НОВОБОБРОВСКОЕ МЕСТОРОЖДЕНИЕ, СРЕДНИЙ ТИМАН)
}

\section{Никулова Н.Ю.,Удоратина О.В.}

Институт геологии Коми НЦ УрО РАН, Сыктывкар, nikulova@geo.komisc.ru

Образования среднерифейской светлинской $\left(\mathrm{RF}_{2} \mathrm{sv}\right)$ свиты, вмещающие редкоземельноредкометалльную минерализацию в пределах Новобобровского рудного поля (Четласский Камень, Средний Тиман) (рис. 1), представлены палеонтологически немой терригенной толщей, в которой в различных соотношениях чередуются сланцевые, алевролитовые и псаммитовые слои.

Выявление особенностей поведения редких и редкоземельных элементов, позволяют уточнить генетическую принадлежность, получить сведения об источниках обломочного материала, палеоклиматических обстановках и палегеодинамических условиях осадконакопления, сделать предположения о степени влияния метасоматических процессов на распределения предполагаемых минералов-концентраторов РЗЭ.

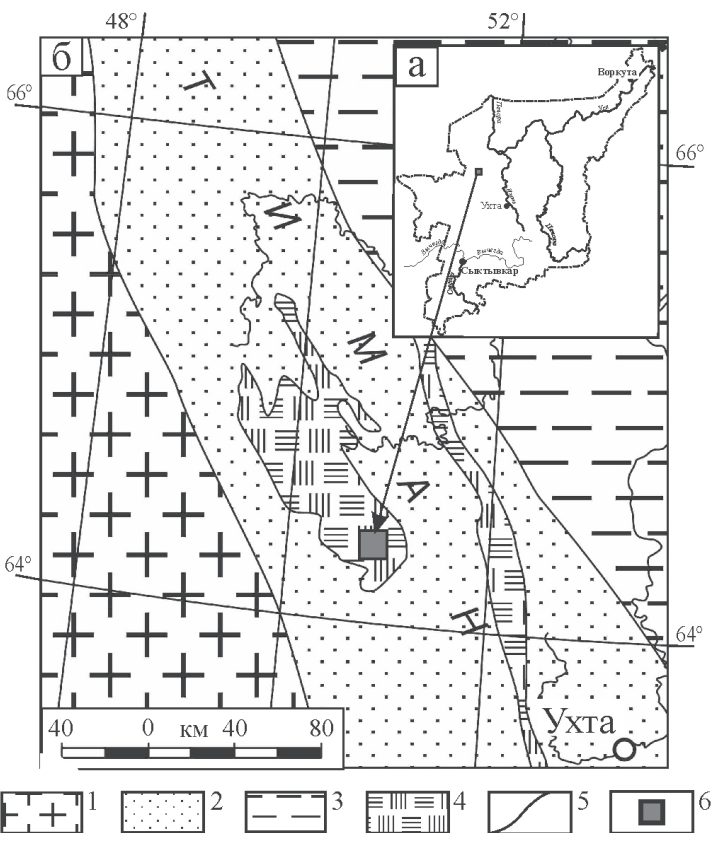

Рис. 1. Схемы: а - расположения Новобровского месторождения; б - тектонического строения Среднего Тимана (по [3]), условные обозначения: 1 - Восточно-Европейская платформа; 2-3 - фундамент Печорской плиты, Тиманский мегаблок: 2 - Тиманский блок; 3 - Ижемский блок; 4 - выходы фундамента на поверхность; 5 - границы тектонических зон; 6 - местоположение Новобобровского рудного поля.

Фактический материал получен при опробовании канав, пересекающих вкрест простирания рудные зоны Новобобровского рудного поля. В выборку вошли пять образцов песчаников светлинской свиты, литолого-геохимические исследования и результаты U-Pb датирования детритных цирконов которых проведены нами ранее [5]. Определение содержаний редких и редкоземельных элементов проведено методом ICP-MS (Agilent 7700x, аналитик к. г.-м. н. Д. В.Кузьмин) в ЦКП «Геонаука» Института геологии Коми НЦ УрО РАН.

Максимальные содержания РЗЭ отмечаются в фенитизированных песчаниках непосредственно рудоносной зоны, минимальные - в слабо измененных песчаниках на периферии рудного поля (табл.). Спектры распределения РЗЭ в четырех образцах песчаников достаточно однородны и характеризуются резко пониженным, по сравнению с UCC содержанием легких РЗЭ, отчетливо выраженной положительной европиевой аномалией и незначительным преобладанием тяжелых лантаноидов над легкими (рис. 2).

Спектры РЗЭ имеют небольшой положительный наклон, характерный для метатерригенных пород, не связанных с вулканизмом. На этом фоне существенной дифференцированностью выделяется спектр обр. G6б/15, отобранного близ рудной кварцевой жилы, в составе которого, по результатам нормативного пересчета присутствует максимальное для всех изученных образцов количество 


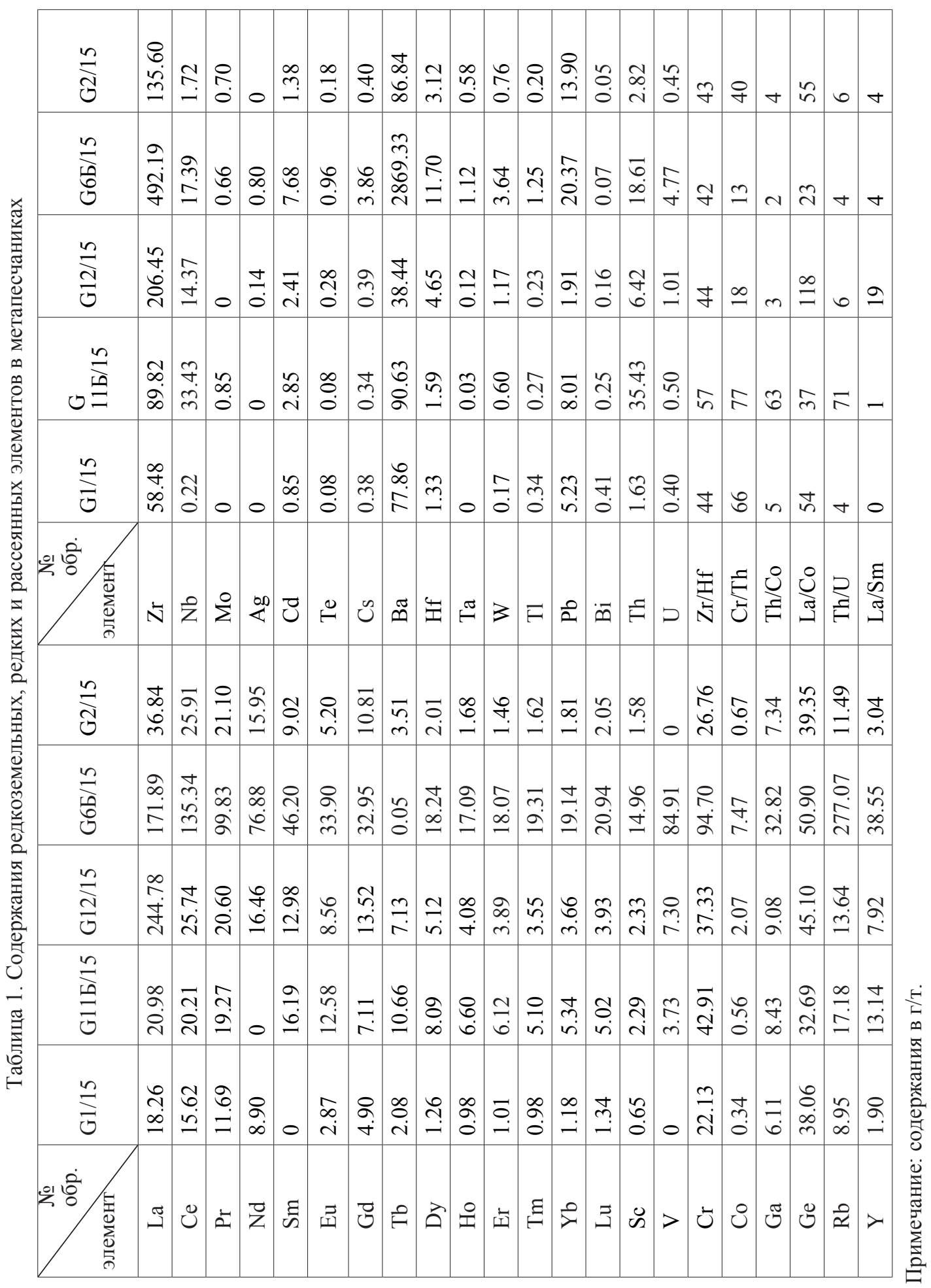




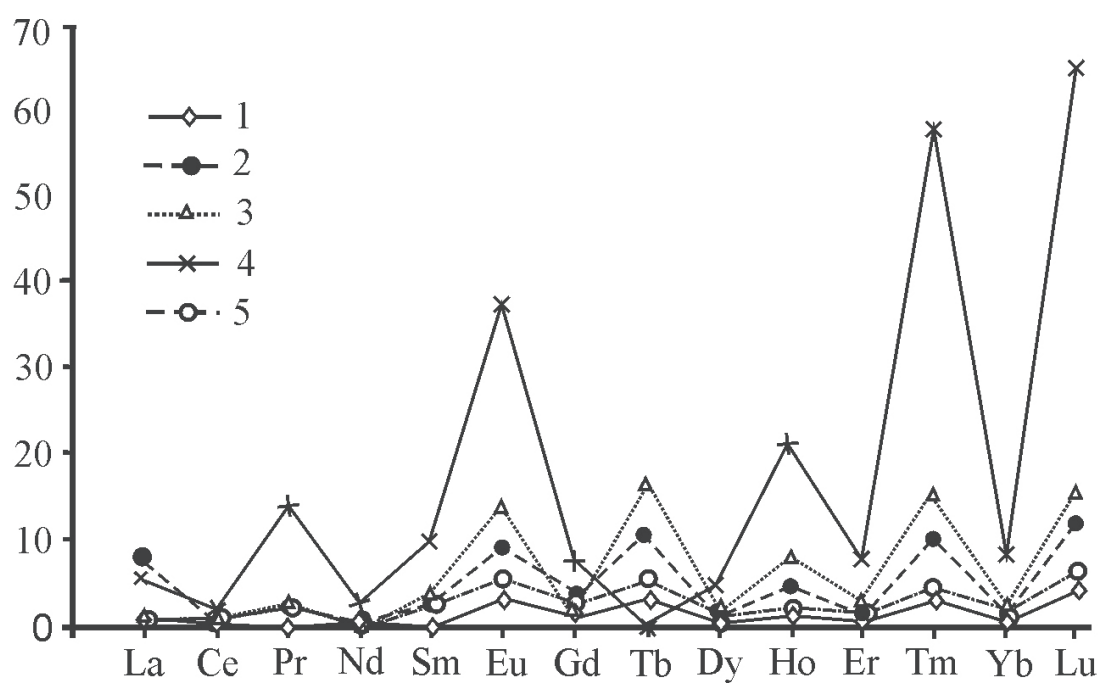

Рис. 2. Нормированные на UCC [4] спектры распределения содержаний Р3Э в песчаниках светлинской свиты. Условные обозначения: 1-5 номера образцов: 1 - G11/15; 2 - G11Б/15; 3 - G12/15; 4 - G6б/15; 5 - G2/15.

полевых шпатов (около 40 мас. \%), слюды (до 40 мас. \%) и рудных минералов - гематита и ильменита (в сумме около $3 \%$ мас. \%) [5].

Количественный показатель суммы РЗЭ зависит от положения точки опробования по отношению к рудоносной зоне и отражает степень влияния метасоматических процессов.

Наименее измененные разновидности песчаников, характеризуются минимальным значением суммы, при примерно равновесном соотношении легких и тяжелых РЗЭ и слабо проявленной европиевой аномалией. В нормальных осадочных породах положительная европиевая аномалия и преобладание тяжелых лантаноидов над легкими, свидетельствуют о присутствии в составе песчаников неизмененных выветриванием основных плагиоклазов. Положительная европиевая аномалия, минимально проявленная в слабо измененных песчаниках (обр. G1/15, G2/15, G11Б/15), усиливается по мере приближения к рудоносной зоне, отражая интенсивность проявления щелочного метасоматоза.

Отмечается практическое отсутствие цериевой аномалии (для четырех образцов $\mathrm{Ce} / \mathrm{Ce}$ *UсC составляет 0.25-0.4, а для обр. G6б/15-2.1) В во всех изученных образцах легкие лантаноиды преобладают над тяжелыми (LREE/HREE $\approx 1.3-7.3$ ). По суммарному содержанию РЗЭ выделяются песчаники: с пониженным содержанием - 66 (слабо измененный песчаник обр. G1/15), со средним содержанием - 124 (обр. G115/15) и 138 (обр. G2/15), высоким - 374 (обр. G12/15) и аномально высоким - 710 г/т (обр. G6б/15 из рудной зоны).

Во всех изученных песчаниках отсутствуют $\mathrm{Cu}, \mathrm{Ni}, \mathrm{Zn}, \mathrm{Be}$, существенные содержания малоподвижных Sc, Zr и Hf, присутствуют лишь в обр. G6б/15 (табл.). В нем же наблюдается максимальное значение соотношения $\mathrm{Zr} / \mathrm{Hf}$ (56), характерное для щелочных метасоматитов. Значения индикаторных соотношения $\mathrm{Cr} / \mathrm{Th}, \mathrm{Th} / \mathrm{Co}, \mathrm{La} / \mathrm{Co}$ имеют весьма широкий разброс и так же отражают зависимость от степени измененности пород [7, 9]. Отношение $\mathrm{Th} / \mathrm{U}[9]$ составляет 4-6, а в песчаниках обр. G11б/15 достигает 71. Слабая измененность, хорошая сортировка и практически кварцевый состав этого песчаника, позволяют предположить, что повышенная концентрация Тh обусловлены присутствием Th-монацита [6]. Песчаник обр.G1/15, для которого была получена цирконовая датировка, характеризуется коэффициентами $\mathrm{La} / \mathrm{Sm}(4,1), \mathrm{Ce} / \mathrm{Sm}(2,9), \mathrm{Yb} / \mathrm{Sm}(0.2), \mathrm{Y} / \mathrm{Sm}(0.34), \mathrm{Ce} / \mathrm{Ce}^{*}$ (0.4) соответствующими мелководным [2] условиям континетальной окраины.

Таким образом, степень дифференцированности спектров распределения РЗЭ отражает степень измененности песчаников в результате фенитизации. Закономерное изменение содержания РЗЭ, свидетельствует о привносе вещества извне. Ярко выраженный европиевый максимум и преобладание тяжелых лантаноидов над легкими характерно для калиевого метасоматоза [1]. Минимальные содержания РЗЭ отмечаются в наименее измененных разновидностях, при этом в них так- 
же отмечается европиевый максимум, связанный с присутствием в песчаниках обломочного материала, образовавшегося в результате разрушения калиевых гранитоидов.

Геологическая позиция изучаемого объекта, как толщи, вмещающей жильную редкометалльноредкоземельную минерализацию, не позволяет использовать традиционно применяемые для реконструкции обстановки осадконакопления терригененных толщ индикаторные соотношения РЗЭ. Однако, рассчитанные нами для наименее измененных пород коэффициенты $\mathrm{La} / \mathrm{Sm}, \mathrm{Ce} / \mathrm{Sm}$ и др. подтверждают сделанные нами ранее выводы о формировании осадков в мелководно-морской среде за счет рециклированных кварцевых пород и, в меньшей степени, кислых магматических пород. Преобладание в спектре РЗЭ песчаников тяжелых лантаноидов, существенно кварцевый состав и высокая глиноземистость, позволяют предположить существование в области размыва коры выветривания по древним метатерригенным породам.

Работа выполнена при частичной финансовой поддержке Комплексной программы фундаментальных исследований УрО РАН, проект 18-45-11007.

\section{Литература}

1. Балашов Ю.А. Геохимия редкоземельных элементов. М.: Наука, 1976. 267 с.

2. Гурвич Е.И. Металлоносные осадки Мирового океана. М.: Научный Мир, 1998. 340 с.

3. Кузнецов Н.Б., Соболева А.А., Удоратина О.В. и др. Доуральская тектоническая эволюция северовосточного и восточного обрамления Восточно-Европейской платформы. Ст. 1. Протоуралиды, Тиманиды и Доордовикские гранитоидные вулкано-плутонические ассоциации севера Урала и ТиманоПечорского региона / Литосфера. 2006. № 4. С. 3-22.

4. Тейлор С. З., Мак-Леннан С. М. Континентальная кора: ее состав и эволюция. М.: Мир. 1988. 384 с.

5. Удоратина О. В., Бурцев И. Н., Никулова Н. Ю., Хубанов В. Б. Обоснование возраста метапесчаников четласской серии - субстрата редкометалльно-редкоземельных месторождений Среднего Тимана: U-Pb датирование детритных цирконов / Геодинамика, вещество, рудогенез Восточно-Европейской платформы и ее складчатого обрамления. Матер. Всерос. науч. конф. с межд. уч-ем. Сыктывкар. ИГ Коми НЦ УрО РАН. 2017. С. 218-219. ISBN 978-5-98491-470-5.

6. Удоратина О.В., Варламов Д.А., Капитанова В.А. Рудная минерализация кварцевых жил Новобобровского месторождения, Средний Тиман: новые данные / Современные проблемы теоретической, экспериментальной и прикладной минералогии (Юшкинские чтения-2016). Матер. мин. семинара с межд. участием. Сыктывкар. ИГ Коми НЦ УрО РАН, 2016. С. 257-258.

7. Condie K. C. Cr/Th ratio in Precambrian pelites from the Kaapvaal Craton as an index of craton evolution // Earth Planet. Sci. Lett., 1990. V. 65. P. 1-12.

8. Cullers R.L. The geochemistry of shales, siltstones and sandstones of Pennsylvanian-Permian age, Colorado, USA: implications for provenance and metamorphic studies / Lithos, 2000. V. 51. P. 181-203.

9. McLennon S.M. Geochemical approaches to sedimentation, provenance, and tectonics. Processes controlling the composition of clastic sediments / Geol. Soc. Amer. Spec. Paper, 1993. V. 284. P. 21-40. 